\title{
Evidences of Large-Scale Shearing from South-Eastern Extension of The Mahakoshal Belt, Covering Parts of Sidhi \& Singrauli Districts of Madhya Pradesh and Sonbhadra District, Uttar Pradesh, India
}

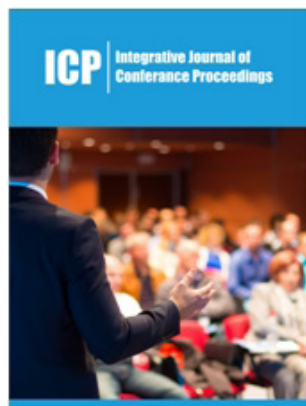

*Corresponding author: Banerji DC, India

Submission: 想 May 23, 2019

Published: 眥September 16, 2019

Volume 2 - Issue 1

How to cite this article: Banerji DC. Evidences of Large-Scale Shearing from South-Eastern Extension of The Mahakoshal Belt, Covering Parts of Sidhi \& Singrauli Districts of Madhya Pradesh and Sonbhadra District, Uttar Pradesh, India. Int J Conf Proc.2(1). ICP.000526.2019.

Copyright@ Banerji DC, This article is distributed under the terms of the Creative Commons Attribution 4.0 International License, which permits unrestricted use and redistribution provided that the original author and source are credited.

\section{Banerji DC*}

India

\begin{abstract}
The WNW-ESE trending arm of the Mahakoshal belt, extending towards south-east in the state of Jharkhand, through U.P, exposes variety of structural features those are uncommon in main Mahakoshals having ENE-WSW trend. The turbidites, said to be characteristic of the Parsoi Formation of the WNW trending arm, appear to be shear generated structures, having imprints across the length and width of the arm. Evidences of bulk flow along the pervasive foliation make it a mylonitic foliation, restricting possibility of survival of primary structures.
\end{abstract}

Overwhelming presence of anticlockwise rotated fabric elements, producing S-C structure in phyllite/ phyllonite and in meta-greywacke, along with frequent presence of 'alpha' and 'delta' type structures, strongly asymmetric ' $\mathrm{S}$ ' and at places ' $\mathrm{Z}$ ' shaped folds and the sheath folds suggest that the ductile shearing with a sinistral shear sense is spread over the entire WNW trending sinuous arm of Mahakoshals. This belt has a strong manifestation on the imagery, maintaining a cross cutting relationship with the ENEWSW trending fabric of the main Mahakoshals and appears to be superposed over it. Evidences suggest it to be a wide and extensive shear zone.

Keywords: Shears; Progressive shearing; Sinistral shear sense; Rotation; Mylonitic Foliation; Turbidites

\section{Introduction}

The Mahakoshals have a WNW-ESE trending arm in the south-eastern corner, especially south of Chitrangi. East of Chitrangi, the main Mahakoshals, continuing with an ENE-WSW trend from Narsighpur district of Madhya Pradesh, continues within the state of Uttar Pradesh and abuts against the Son River (Figure 1). The WNW-ESE trending arm, however, continues much to ESE and traceable even within the state of Jharkhand after crossing over the state of Uttar Pradesh.

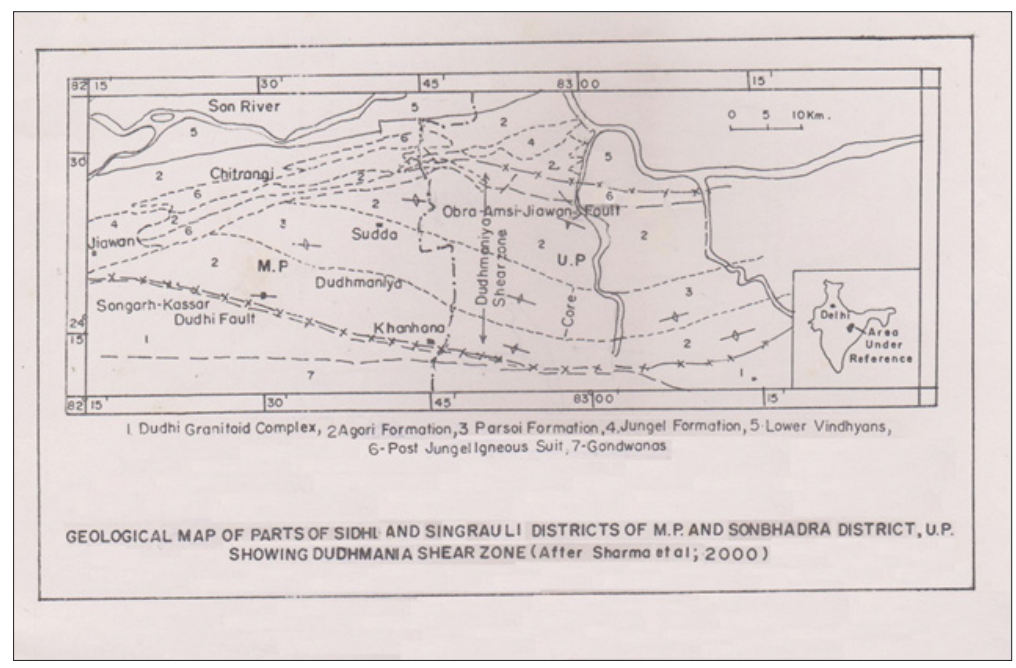

Figure 1: Geological sketch map of parts of Sidhi and Singrauli districts of M.P. and Sonbhadra district of U.P. 
Explanation to this change of trend from ENE to WNW, and the nature of contact between the two arms of Mahakoshals, is barely available in the existing literature. Banerji [1,2] reported large scale non-coaxial shearing of Mahakoshal rocks, resulting into a WNWESE trending sinuous belt, having imprints of superimposition over the ENE trending main Mahakoshals. The superimposition of the WNW fabric is well supported by the satellite image of the area. Sharma [7], however, has reported the presence of turbidites restricted within the WNW trending arm of the Mahakoshals.

Present work further analyses the ground evidences to ascertain if the differently oriented arm of Mahakoshals is a result of ductile flow, producing a WNW trending mylonitic foliaton.

\section{Geologic setting}

The ENE-WSW trending narrow belt of Mahakoshal rocks extends along the Narmada and Son rivers between Barmanghat (Narsinghpur, Madhya Pradesh) in the west to Palamau (Jharkhand) in the east. This belt is represented by rocks like quartzite, phyllite, dolomite, meta basics and banded ferruginous chert. The lower division of the Mahakoshals, occupying the western and central part of the belt is known as Agori Formation and is represented by a sequence of basal quartzite interbedded with meta basics and overlained by dolomites with chert inter bands. The eastern part of the belt is dominated by meta basics, banded ferruginous chert, phyllite and meta-greywacke with near absence of carbonates. Nair et al. [3] have considered the meta basics / ultramafic flows occurring near Chitrangi to be the lowermost part of Mahakoshals and named them 'Chitrangi Formation'. Sharma et al. [8] however, have considered these meta basics / ultramafic flows as Post Jungel igeous suit. The argillite-meta greywacke association occupying central part of the WNW trending arm of the Mahakoshals (Figure 1) is flanked on either side by rocks of Agori Formation and has been considered \{Nair et al. [3]\} as uppermost 'Parsoi Formation'. The Parsoi rocks also include turbidites, restricted only to this part of the belt [7]. The southern margin of the eastern Mahakoshal belt is affected by intrusions of granitic to granodioritic and syenitic plutons [9]. These igneous rocks are generalized as Dudhi granitoid in the existing geological maps.

Banerji [2] reported the presence of a major shear zone in the south-eastern part of Mahakoshal belt and considered the WNWESE trending tract of Agori and Parsoi Formation of the south-east as mylonites, representing his 'Dudhmania Shear Zone'. Ductile shearing along the southern boundary of the WNW trending Mahakoshal belt of south-east, is also discussed by Roy \& Devrajan [6].

\section{Structural features}

In the WNW trending arm of the Mahakoshals, the trend of the foliation is $\mathrm{N} 80^{\circ} \mathrm{W}-\mathrm{S} 80^{\circ} \mathrm{E}$ in the western end, swerving to $\mathrm{N} 60^{\circ}$ $\mathrm{W}$-S60 $60^{\circ}$ in the central part and again swinging to $\mathrm{N} 80^{\circ} \mathrm{W}-\mathrm{S} 80^{\circ} \mathrm{E}$ in the eastern end of the belt. This change in the trend of foliation imparts a sinuous appearance to the belt. The dip of the foliation is sub-vertical.

Northern margin of Dudhi Granitoid, located south of the Songarh-Kasar-Dudhi (SKD) fault bordering WNW trending belt of Mahakoshals, record ample evidences of ductile shearing. The rock locally acquires gneissosity because of alignment of stretched feldspars alternating with layer lattice minerals. The granitoid shows imprints of two obliquely running planes, having an angle of about $10^{0}$ to $12^{\circ}$ between them (Figure 2). While, the feldspar phenocrysts are extremely stretched along pervasive ' $C$ ' planes representing mylonitic foliation, the obliquely oriented grains along 'S' planes show regular offsest by the mylonitic foliation, imparting an ophthalmic shape to the phenocrysts. Crude rotation of the ' $\mathrm{S}$ ' planes gives impression of a strain sensitive fabric.

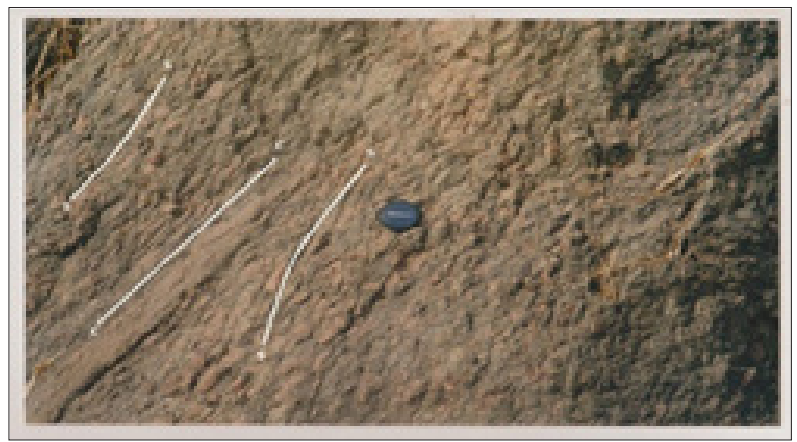

Figure 2: Sheared granitoid (pink gneiss) from Kanhana, north of Singrauli.

North of the SKD fault, exposures of greywacke/phyllite/ phyllonite are common, representing the WNW trending Mahakoshal belt. Development of a strain sensitive fabric with ' $\mathrm{S}$ ' planes rotated both clockwise and anticlockwise (Figure 3a \& 3b) directions, in mesoscopic scale, is common all along the rocks of bordering zone. The ' $\mathrm{C}$ ' planes define mylonitic foliation, running parallel to the boundary of the WNW trending Mahakoshal belt. The angle between these two planes, near the flank, is about $15^{\circ}$. This type of rotational feature persists across the length and width of the WNW trending Mahakoshal belt. The angle between the two planes reduces to less than $10^{\circ}$ in the central part of the belt.

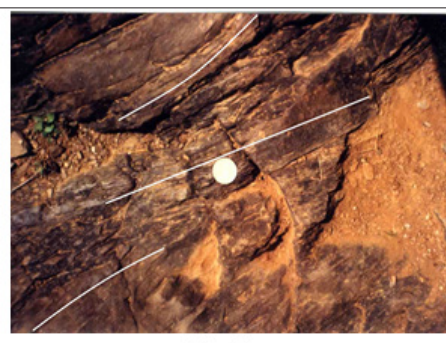

Fig. 3a

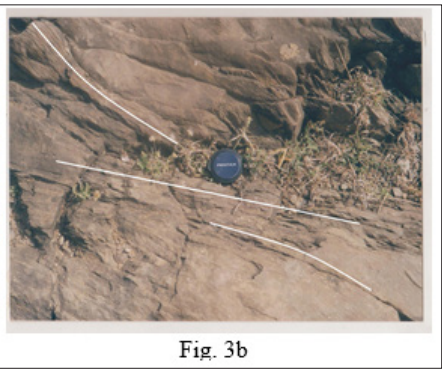

Figure 3: Strain sensitive fabric developed in phyllite/phyllonite. The coin is placed on 'C' plane dominated area, while above and below the coin 'S' planes show rotation. 
Also, the ubiquitously present Quartz veins and the chert bands of the peripheral area exhibit variety of shortening and extensional features. The bands which are oriented parallel to the pervasive foliation (' $\mathrm{C}$ ' planes) show stretching and boudinaging. Boudins, thus created within the stretched part, lying parallel to the flow planes, are further rotated during the progressive movement and play the role of excellent shear sense indicators (Figure $4 \mathrm{a} \& 4 \mathrm{~b}$ ). On the contrary, veins/bands having oblique orientation to the flow plane display shortening by compression, producing short hinges. With the progressive movement, the limbs of the short hinges acquire parallelism with the flow direction and get considerably stretched. This phenomenon is quite corroborative with the instantaneous extensional and shortening regimes, conforming flow along mylonitic foliation. The extent of stretching of the limbs along the ' $\mathrm{C}$ ' planes, during the progressive deformation, also indicates the amount of flow involved.

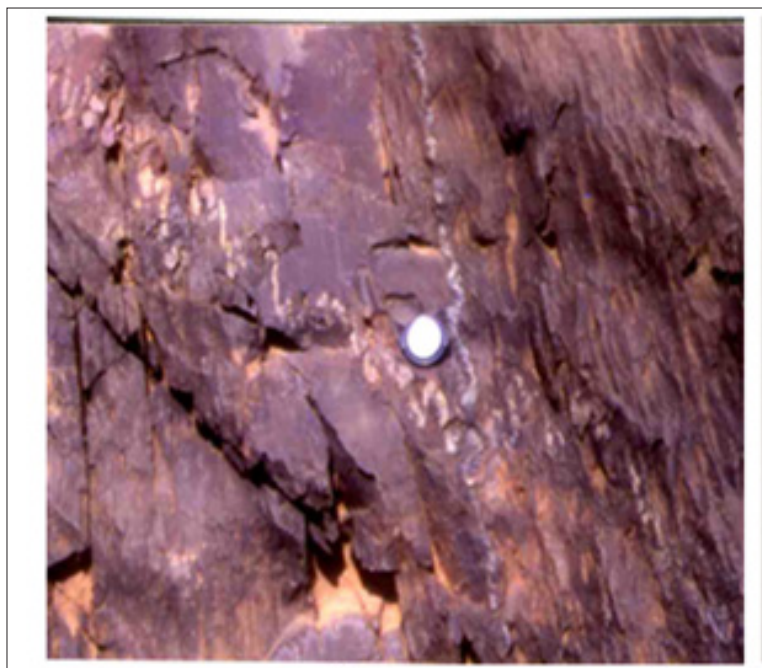

Fig. $4 \mathrm{a}$

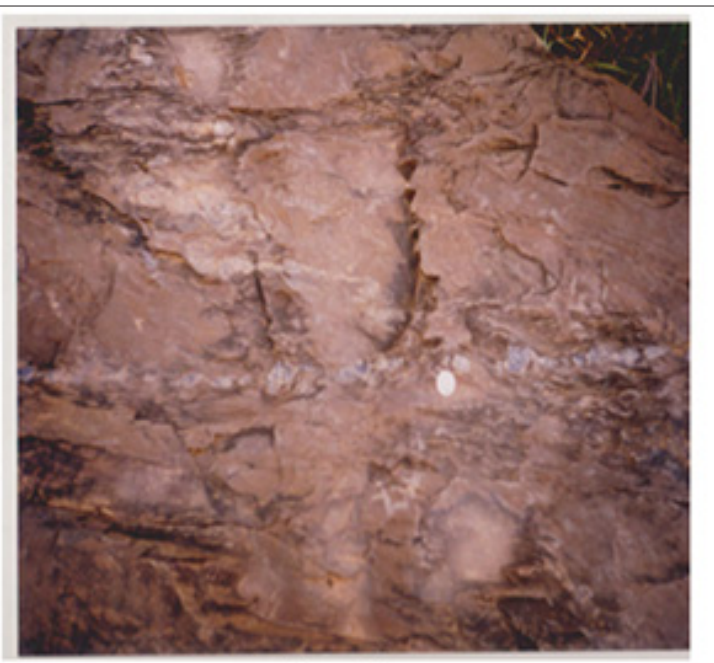

Fig. 4b

Figure 4: Shortened and boudinaged (extended) quartz veins oriented oblique and parallel to mylonitic foliation respectively. Note the anticlockwise rotation of the boudins, and extended limbs and short hinges in obliquely oriented quartz veins. The extent of stretching of the limbs in Figure b is also noteworthy. Sense of shear is sinistral.

Formation of 'alpha' and 'delta' structures (Figure 5a \& 5b), within the stretched bands are again a common phenomenon throughout the belt. The boudins formed during stretching are rotated either clockwise or anticlockwise, depending upon the prevailing dextral or sinistral movement. In most of the cases, however, the shear sense deduced from such rotated boudins indicate a sinistral sense of movement. One of the chert bands from east of Dudhmania exhibit a complex structure, which appears to have resulted from change in direction of non-coaxial movement, from dextral to sinistral, and consequent reverse rotation of the boudins (Figure 6).

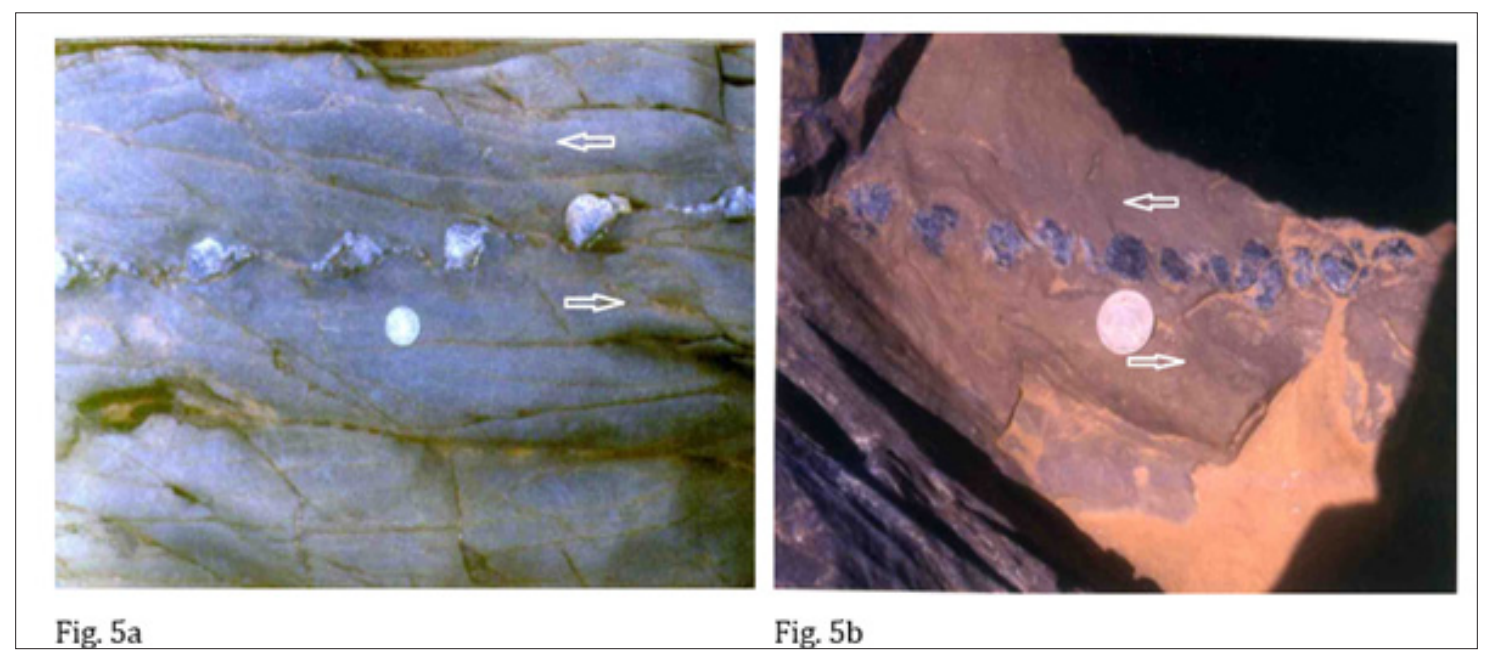

Figure 5: (a) Quartz vein showing 'alpha' structure. (b) Quartz vein showing 'delta' structure. Sense of shear is sinistral. 


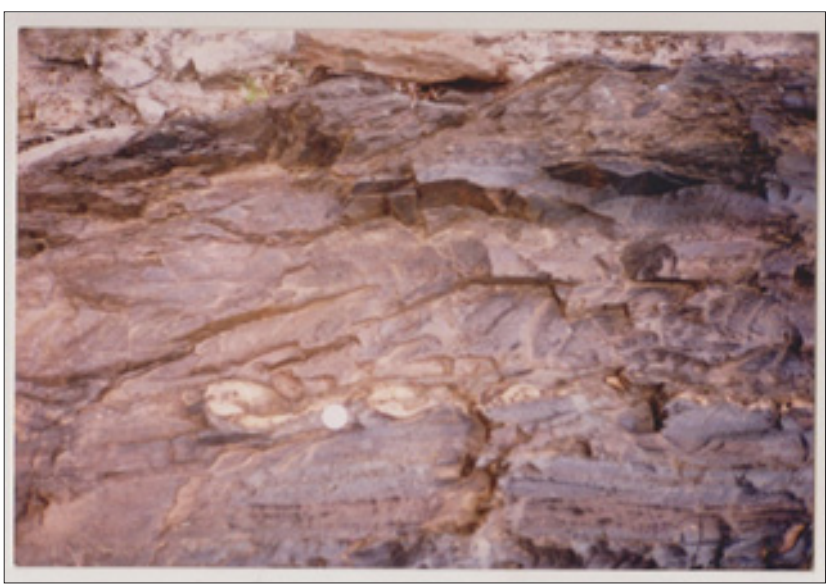

Figure 6: Complex structure showings reverse rotation in pre-existing rotated boudins. The over tightening is caused probably by reverse rotation of the earlier rotated boudins in chert band.

The over tightening of ' $\mathrm{Z}$ ' fold, represented by a chert band observed near Dudhmania and its reverse rotation (Figure 7) also suggest that initial sense of asymmetry of folds (i.e. dextral as indicated by ' $\mathrm{Z}$ ' folds) was subjected to reverse shearing (sinistral) during the progressive non-coaxial deformation [5].

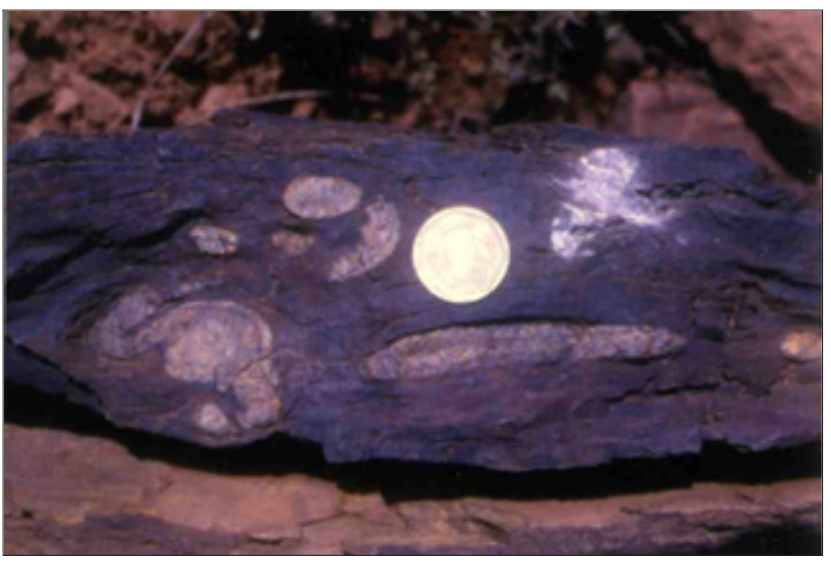

Figure 7: Compex structure produced by reverse rotated ' $Z$ ' fold in the chert band. Because of reverse rotation, the lower hinge of ' $Z$ ' fold is rotated upward, and the upper hinge has come closer to the lower hinge. The extended / boudinaged fragments of the upper and lower limbs have moved inward (towards center).

Chert bands of this area also preserve a variety of folds, tight to isoclinal and asymmetric in nature. Both ' $\mathrm{S}$ ' and ' $\mathrm{Z}$ ' shaped folds are represented; however, ' $S$ ' shaped folds predominate over the other type. These mesoscopic folds have low $\left(<30^{\circ}\right)$ easterly plunges. However, steep $\left(50^{\circ}-70^{\circ}\right)$ easterly plunges are also observed in the obliquely trending (NNE-SSW to NNW-SSE) shortened chert bands. Anticlockwise rotation of the axial planes of near isoclinal folds and their amplification (Figure 8) is also a regular phenomenon in this part of the belt. Sheath folds with an eyed outcrop pattern and the textbook type plane non-cylindrical sheaths (Figure 9) are also represented in the area having proximity to the central belt of Parsoi Formation of Nair et al. [3].

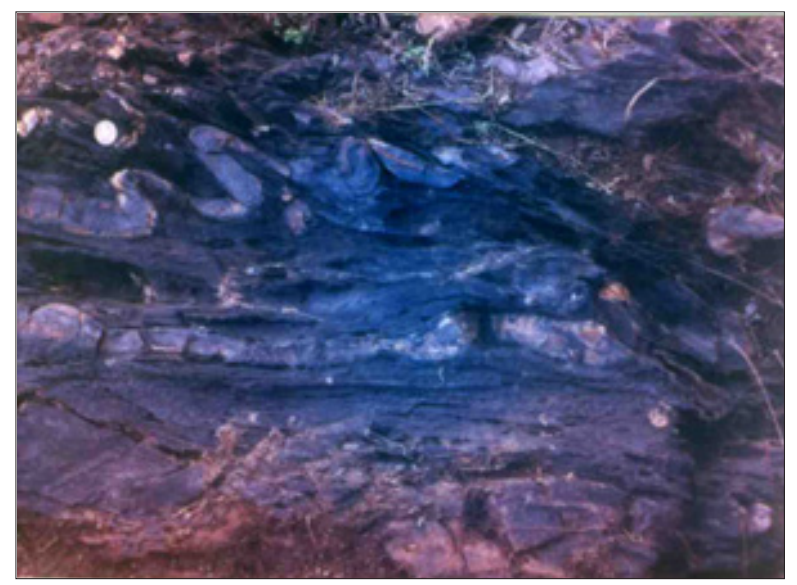

Figure 8: Anticlockwise rotated axial planes of near isoclinal ' $S$ ' folds in chert band. Shear sense is sinistral.

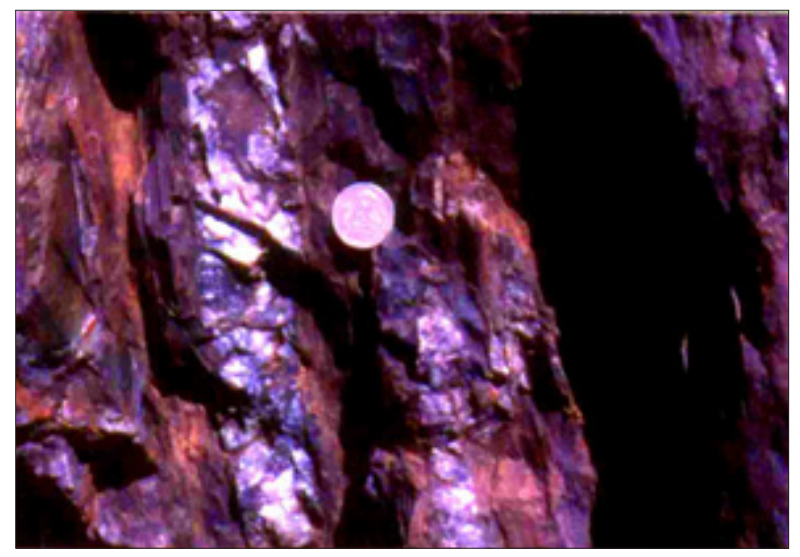

Figure 9: Sheath fold. Of the two white colored chert bands, the one present to the right of the coin has produced plane non cylindrical sheath fold.

Further towards the central part of the belt, i.e. near the belt of Parsoi rocks of Nair et al. [3], the greywacke exhibit presence of numerous, thin, siliceous lamellae, concentrated as discontinuous bands. Extent of such bands is restricted to a few tens of meters, tapering at either ends before disappearance. These siliceous lamellae, in fact, get dissipated within the greywacke, leaving behind still traceable faint markings. Within the bands, the lamellae are stretched, rotated and shortened and displaced along the long axis, depending upon the orientation of the lamellae with respect to the direction of flow. The rotational component of flow is exhibited by rotation of the siliceous lamellae having obliquity to the flow plane (Figure 10). Rotation of these quartzose lamellae very often produce a pseudo cross bedding. Nevertheless, these pseudo cross bedded structures occur in close association with tight rootless miniature folds (Figure 11), indicating that such structures are the products of intense deformation [4]. These structures are likely to be mistaken for turbidites. However, as discussed earlier, evidences of bulk flow along the pervasive foliation, ubiquitously present in the belt, reduces the possibility of existence of any primary structure. Such structures, therefore, represent secondary structures, produced by progressive shearing of the rocks. 


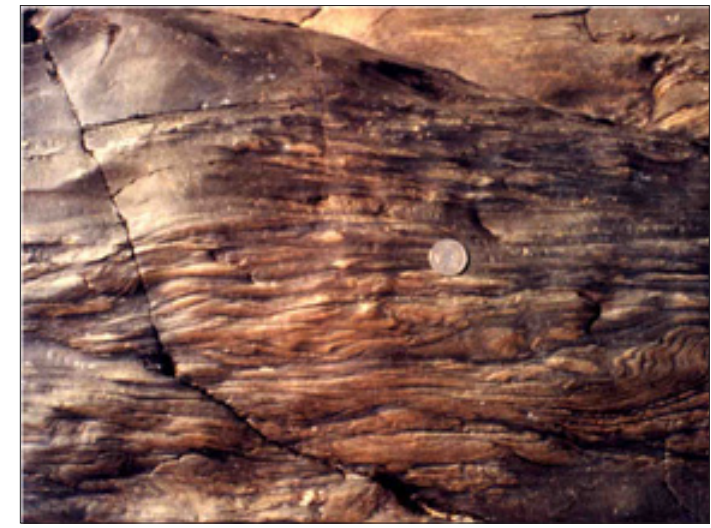

Figure 10: Anticlockwise rotation of siliceous lamellae having obliquity to the flow plane (bottom right) in metagreywacke. Note the systematic partitioning of the rotational component by discrete shear planes and presence of rootless folds (below coin). Shear sense is sinistral.

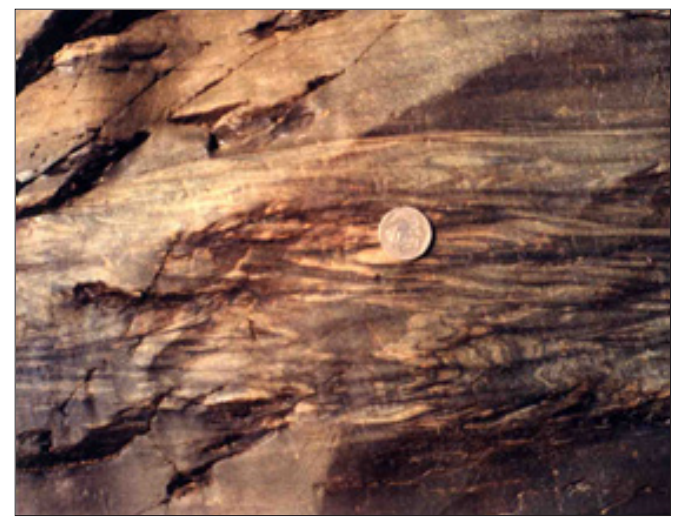

Figure 11: Pseudo cross bedding associated with rootless folds (above and below the coin). Shear sense is sinistral.

Close to the central belt of Parsoi Formation, these siliceous lamellae are present only as small discontinuous patches within the meta-greywacke, mostly as hinges of small folds with markedly oblique relationship with the flow plane. Continuity of these obliquely oriented and highly folded lamellae are conspicuously broken along the discrete planes representing foliation. The rock itself acquires a crudely banded nature with alternate light and darker bands (Figure 12).

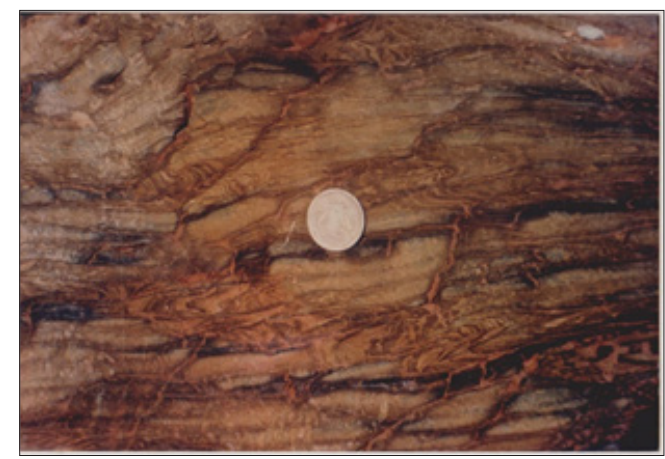

Figure 12: Crudely banded greywacke with traces of obliquely running siliceous lamellae.
Remarkably, adjacent to Parsoi belt, the chert bands, both ferruginous and nonferrous types, drastically reduce in number. They, however, continue displaying rotation of the axial planes by a dominant sinistral flow (Figure 13). Greywacke of this zone attains a well-defined banded nature, very likely to be confused with turbidites. The alternate light and dark bands are arranged parallel to the foliation and show shortening features, wherever there is an obliquity to the flow plane, differentiating them from the turbidites, the rock becomes a classic banded mylonite (Figure 14), with a marked sinistral shear sense.

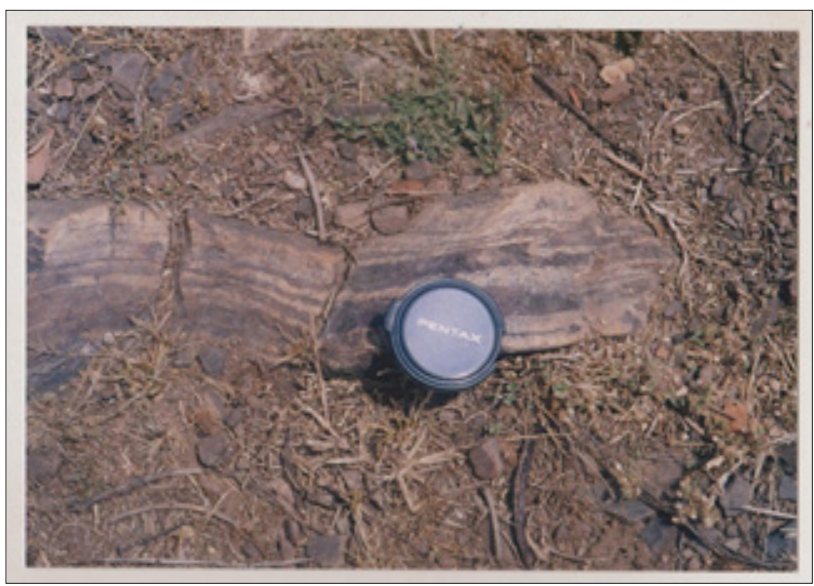

Figure 13: Banded ferruginous chert showing anticlockwise rotation.

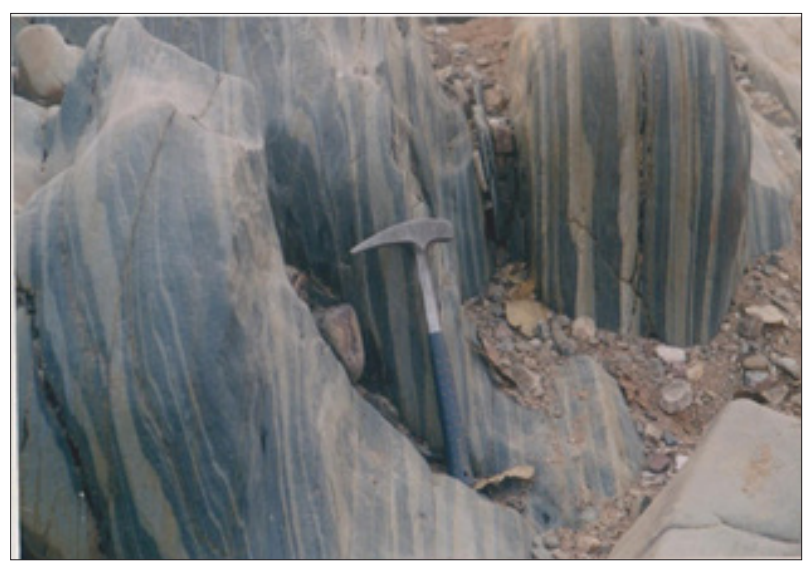

Figure 14: Banded mylonite. Alternate light and dark bands are arranged parallel to the foliation and show shortening/rotational features, wherever there is an obliquity.

In the central belt of Parsoi Formation, the banded mylonite passes into ultra mylonite with still retaining the banded nature. Rocks are friable and show faster denudation. The alternate dark and light bands, however, become thinner with minimum obliquity between them. Rotational features continue as pressure shadows (Figure 15), very helpful in differentiating them from a turbidite. A very strong and close spaced flow plane representing mylonitic foliation is preserved all through the Parsoi belt. Near-complete transposition and rotation of oblique planes produce localized pseudo cross bedding (Figure 16). However, without a holistic approach, differentiating them from a normal turbidite is difficult. Rarely, small, rounded, relatively stiff mass of rock (isotropic) 
appear as rotated segments wrapped within the intensely foliated mass. These rounded segments show a crude sigmoidal trail of the internal foliation, oblique to the external foliation i.e. the foliation present in the wrapping mass (Figure 17). This represents the presence of a component of simple shear flow along the foliation present in the wrapping mass, causing rotation to the relatively stiff and isotropic material.

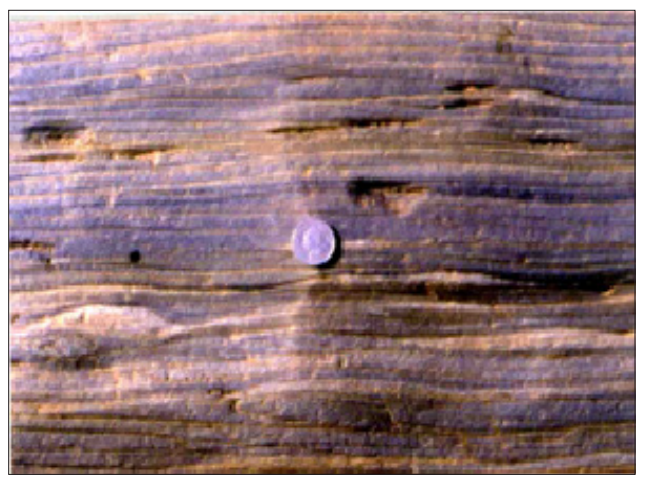

Figure 15: Layered ultramylonite with rotated pressure shadow (near left margin).

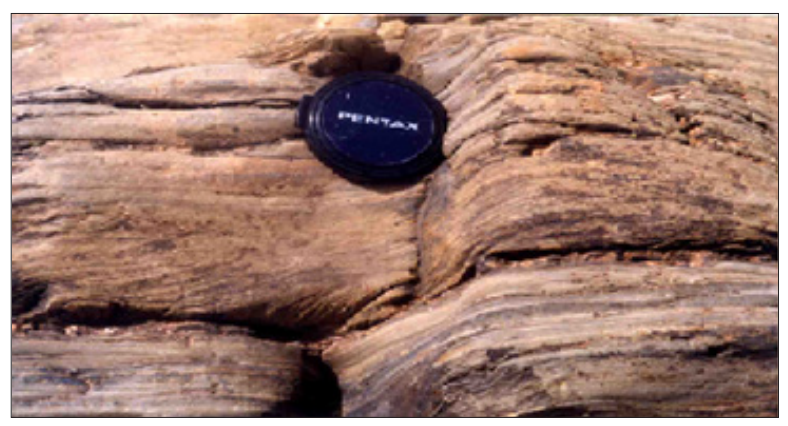

Figure 16: Near complete transposition and rotation of planes / siliceous lamellae in phyllite/ phyllonite. Note the presence of pseudo cross bedding (below lens cap).

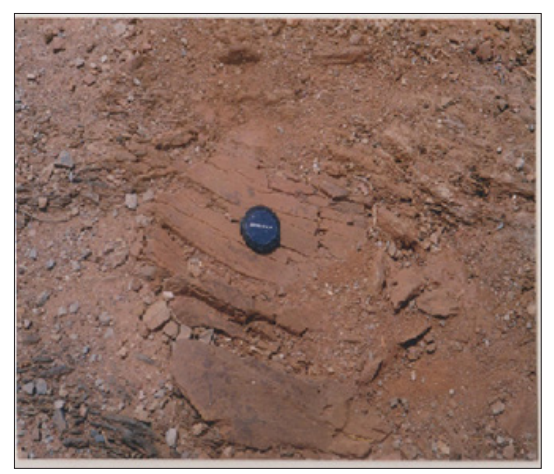

Figure 17: Small, rounded, relatively stiff mass, present as rotated segment, wrapped within the intensely foliated ultramylonite. The rounded segment shows a crude sigmoidal trail of the internal foliation, oblique to the external foliation. Shear sense is sinistral.
The Parsoi belt, having a width of about $2 \mathrm{~km}$, is remarkably devoid of chert bands. Innumerable thin quartz veins, sub-parallel to the mylonitic foliation, however, traverse this belt. These quartz veins are also affected by shearing and rendered as quartz mylonites.

The commonest micro shape fabric in meta-graywacke, near the margin of the WNW trending arm of Mahakoshals, is a porphyroclastic texture where the 'porphyroclasts' are wrapped around by quartz ribbons and muscovite flakes (Figure 18). Quartz veins present in the entire belt are rendered quartz mylonite showing a micro fabric predominantly of S-C type (Figure 19). Presence of synthetic fractures/ slips in chloritoid porphyroclast of phyllonite/ultramylonite (Figure 20) also represents a component of simple shear (sinistral) affecting the rocks.

Minor faults with sinistral shift of the trail of vein quartz boudins/blocks (Figure 21), present near the southern margin, further confirm continuity of shear deformation till much late, even after hardening of the deforming mylonite.

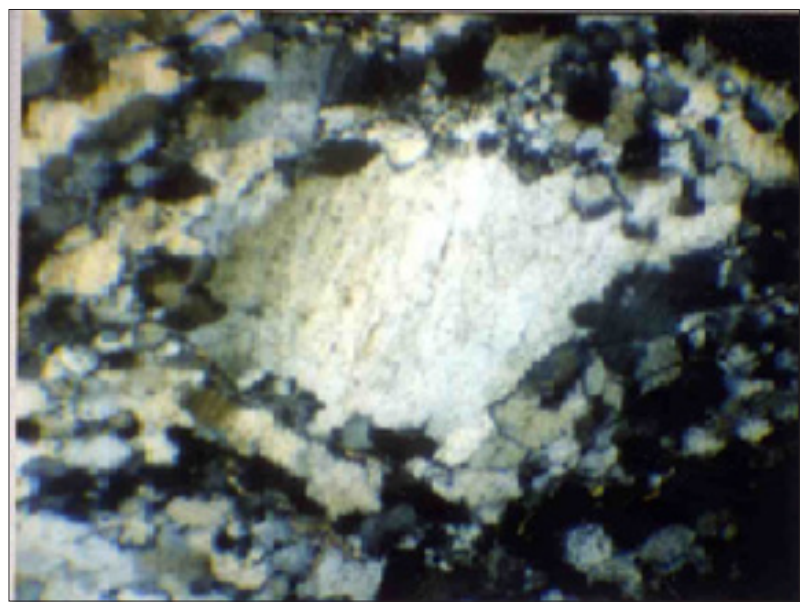

Figure 18: Quartz porphyroclast wrapped by quartz ribbon and muscovite flakes. Crossed nicols, 32X.

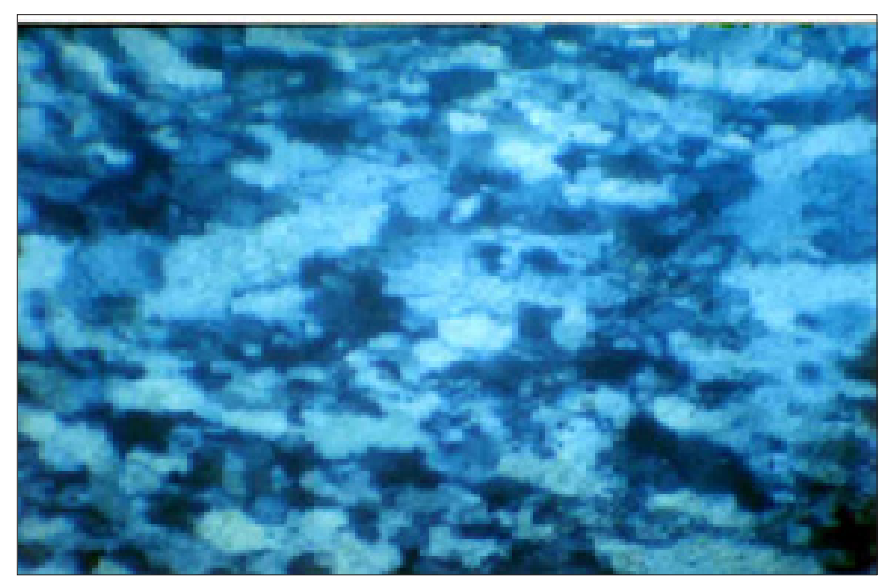

Figure 19: S-C fabric shown by quartz mylonite. Crossed nicols, 3X. Shear sense is sinistral. 


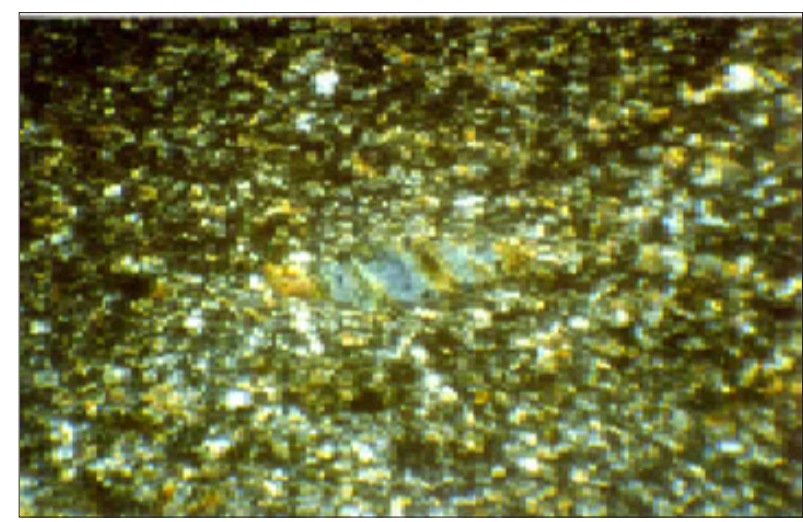

Figure 20: Synthetic fracture/slip in chloritoid porphyroclast within phyllite. Crossed nicols, 3X. Shear sense is sinistral.

\section{Supportive evidences from remote sensing}

In satellite imagery, the WNW trending arm of the Mahakoshal is represented as a sinuous belt hitting against the ENE-WSW trending arm of the main Mahakoshals. The belt has a characteristic broom stick fabric. This uncommon, very close spaced, fabric is different from rest of the Mahakoshals. The close spaced fabric has

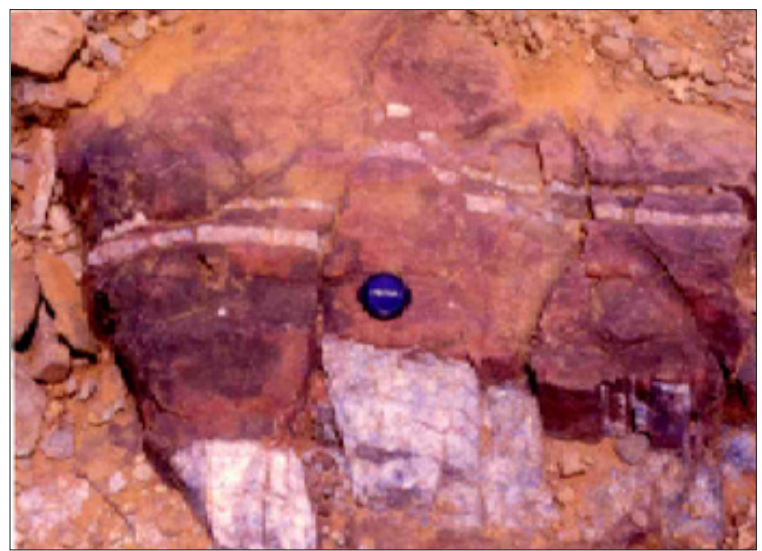

Figure 21: Fault affecting the quartz vein resulting in trail of quartz boudins/blocks. A sinistral shift.

a cross cutting relationship with the ENE-WSW trending fabric of the main Mahakoshals, as is seen west of Obra (Figure 22). In the strike continuity, south of Chitrangi, the WNW-ESE fabric of the sinuous belt abuts / merges into the main Mahakoshal belt. This fabric appears to be superposed over the fabric present in the northern main Mahakoshals.

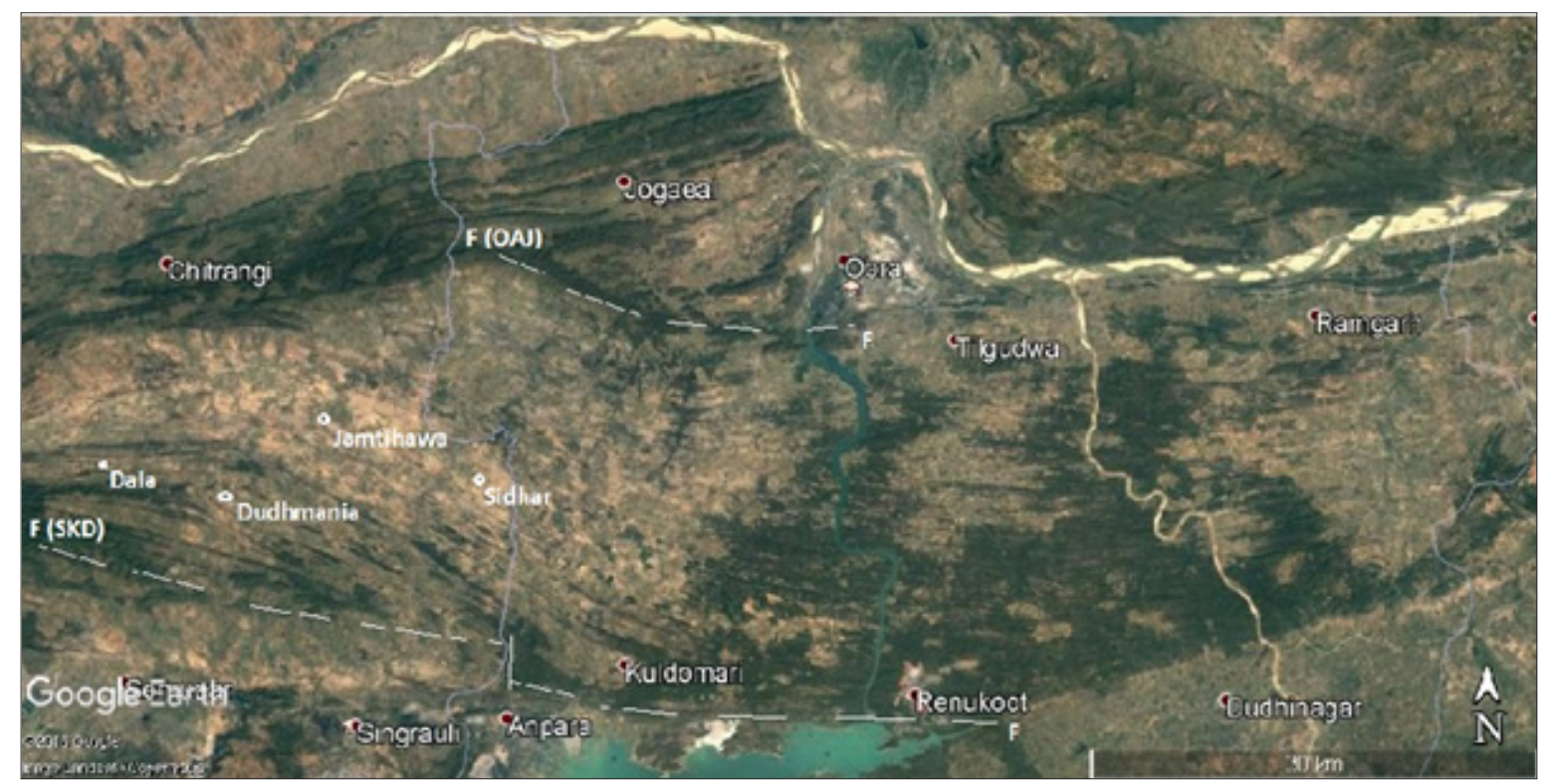

Figure 22: Satellite image showing the sinuous belt of the Sidhi and Singrauli districts of M.P. and Sonbhadra district of U.P. The northern Obra-Amsi-Jiawan (OAJ) fault (F) and the southern Songarh-kasar-Dudhi (SKD) fault is marked with broken white lines.

\section{Discussion and Conclusion}

The main belt of Mahakoshal, extending between Narsinghpur in the west to Sidhi in east, has a dominant ENE-WSW trend, representing the axial traces of D1 and D2 structures. However, the southeastern extension of the belt, lying between Obra-AmsiJiawan fault (OAJ) and the Songarh-Kasar-Dudhi (SKD) fault, shows a WNW-ESE trend. This trend clearly is superimposed on the main Mahakoshal trend, well depicted in imagery, and does not appear to have resulted by folding.
The overwhelming presence of rotation of fabric elements all along the length and width of the WNW trending arm, frequent presence of 'alpha' and 'delta' type structures, strongly asymmetric 'S' and at places ' $\mathrm{Z}$ ' shaped folds and the sheath folds suggest that the belt has undergone strong ductile deformation. Transposition of fabric along the WNW-ESE trending foliation is also amply clear all through the belt. This foliation, therefore, represents a 'mylonitic foliation'. The stretching and boudinaging of chert bands and quartz veins along this foliation and shortening (tight folding) of 
the obliquely oriented features, is suggestive of bulk flow along the foliation. Rotation of the stretched boudins and of the axial planes of near isoclinal folds, however, indicates that the deformation was non-coaxial and progressive in nature. The dominance of anticlockwise rotated fabric and shape symmetry indicate existence of a sinistral sense of movement, though, at places, clockwise rotated fabric along with ' $\mathrm{Z}$ ' folds are also observed.

Finally, it is obvious that the shear generated structures present in the sinuous belt were mistaken for turbidites in earlier literature. Close association of these structures with shear sense indicators further helps in differentiating them from normal syn-sedimentary structures (turbidites) formed in tectonically active basins. Overwhelming presence of rotational features in chert bands and in quartz veins, further ascertains that the terrain is representative of a flow regime. Splendid representation of the belt in satellite imagery, clearly showing a superposed trend, leaves no ambiguity in mind in differentiating the sinuous belt from the ENE-WSW trending main Mahakoshals. The name DUDHMANIA SHEAR ZONE $\{$ Banerji [1]\} was proposed for this remarkable belt.

\section{References}

1. Banerji DC, Prasad A (1997) A report on specialized thematic mapping of the mahakoshal group of rocks around Chakaria Kalan. Unpub Prog Rep Geol Surv Ind.
2. Banerji DC (2011) A discussion on structural aspects of gold bearing belt of Singrauli and Sidhi districts of Madhya Pradesh and Sonbhadra district, Uttar Pradesh. Journal of Economic Geology and Geo resource Management 8(1-2): 85-96.

3. Nair KK, Jain SC, Yedekar DB (1995) Stratigraphy, structure and geochemistry of the mahakoshal greenstone belt. GSI Mem 31: 403-432.

4. Passchier CW, Myors JS, Kroner A (1991) Field geology of high-grade gneiss terrains. Narora publishing House, New York, USA.

5. Ramsay JG, Casey M, Kligfield R (1983) Role of shear in development of the halvetic fold-thrust belt of Switzerland. Geology 11(8): 439-442.

6. Roy A, Devrajan MK (2000) A reappraisal of the stratigraphy and tectonics of the palaeo-proterozoic mahakoshal supracrustal belt, Central India. Geol Surv Ind 57: 79-97.

7. Sharma RS (2009) Cratons and Fold Belts of India, lecture notes in earth sciences. Berlin Heidelberg, Germany.

8. Sharma DP, Sinha VP, kannadasan T, Khan MA, Mehrotra RD, et al. (2000) Gold mineralization in eastern part of son valley greenstone belt, Sidhi and Sonbhadra districts. Geol Surv Ind 57: 271-278.

9. Soni MK, Jha DK (2001) Mahakoshal greenstone belt and associated gold mineralization. Journal of Geological Society India 64: 317-326. 